\title{
Correction to: Kallistatin inhibits tumour progression and platinum resistance in high-grade serous ovarian cancer
}

\author{
Huan $\mathrm{Wu}^{1,2+}$, Rongrong $\mathrm{Li}^{1,2+}$, Zhiwei Zhang ${ }^{1,2}$, Huiyang Jiang ${ }^{1,2}$, Hanlin $\mathrm{Ma}^{1,2}$, Cunzhong Yuan ${ }^{1,2}$,
} Chenggong Sun ${ }^{1,2}$, Yingwei $\mathrm{Li}^{1,2}$ and Beihua Kong ${ }^{1,2^{*}}$ (D)

\section{Correction to: J Ovarian Res (2019) 12:125 https://doi.org/10.1186/s13048-019-0601-6}

The original article [1] contains errors in Fig. 3c, Results and Discussion. The picture of cell cycle analysis of A2780 si-KAL in the original publication was incorrectly a repeat of A2780 si-NC, and the correct picture of A2780 si-KAL is updated.

Additionally, the data of G2/M phase and S phase are switched in Fig. 3c. Correspondingly, "G2 phase" in Results and Discussion of the original article (page 5, left column, line 16 and page 6 , right column, line 22) should be changed to "S phase", which still indicated that kallistatin inhibited the proliferation of ovarian cancer cells. The corrected Fig. 3 appears below.

The authors sincerely apologize for the errors. The errors do not affect the conclusion of the article.

Published online: 13 March 2020

\section{Reference}

1. Wu H, Li R, Zhang Z, et al. Kallistatin inhibits tumour progression and platinum resistance in high-grade serous ovarian cancer. J Ovarian Res. 2019;12:125. https://doi.org/10.1186/s13048-019-0601-6.

\footnotetext{
The original article can be found online at https://doi.org/10.1186/s13048019-0601-6

*Correspondence: kongbeihua@sdu.edu.cn

${ }^{\dagger}$ Huan Wu and Rongrong Li contributed equally to this work.

'Department of Obstetrics and Gynecology, Qilu Hospital of Shandong University, 107 Wenhua Xi Road, Ji'nan, Shandong 250012, People's Republic of China

${ }^{2}$ Shandong Key Laboratory of Gynecologic Oncology, Qilu Hospital of

Shandong University, Ji'nan, Shandong, People's Republic of China
}

(c) The Author(s). 2020 Open Access This article is licensed under a Creative Commons Attribution 4.0 International License, which permits use, sharing, adaptation, distribution and reproduction in any medium or format, as long as you give appropriate credit to the original author(s) and the source, provide a link to the Creative Commons licence, and indicate if changes were made. The images or other third party material in this article are included in the article's Creative Commons licence, unless indicated otherwise in a credit line to the material. If material is not included in the article's Creative Commons licence and your intended use is not permitted by statutory regulation or exceeds the permitted use, you will need to obtain permission directly from the copyright holder. To view a copy of this licence, visit http://creativecommons.org/licenses/by/4.0/. The Creative Commons Public Domain Dedication waiver (http://creativecommons.org/publicdomain/zero/1.0/) applies to the data made available in this article, unless otherwise stated in a credit line to the data. 


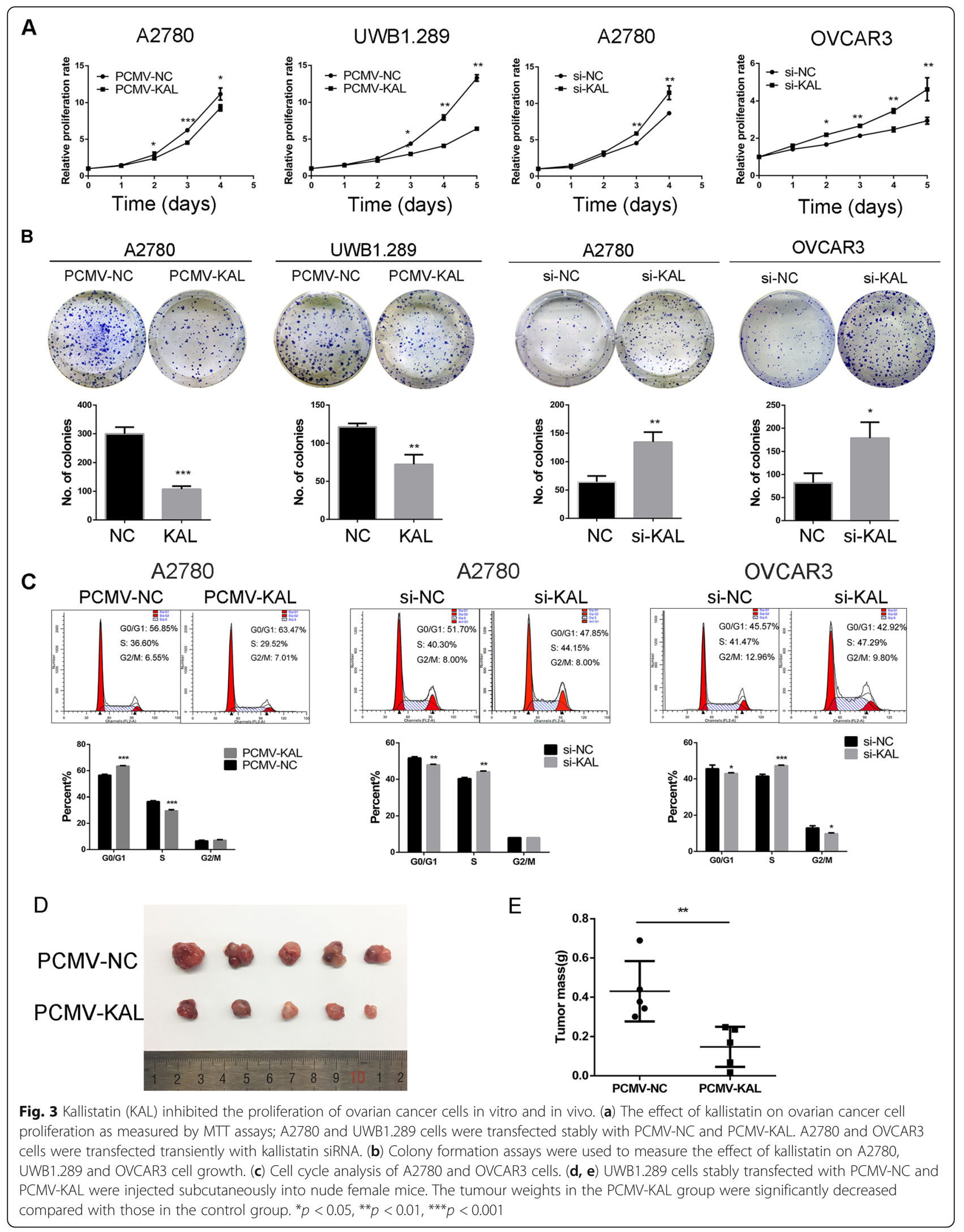

